\title{
The Correlation Between Students' Critical Thinking and Their Writing Ability in Writing Class: A Study of the Third Semester Students of English Education Department UINSA
}

\author{
Hilda Izzati Madjid \\ Faculty of Education and Teacher Training \\ UIN Sunan Ampel Surabaya \\ Surabaya, Indonesia \\ Huriyah Lutfiyah \\ Faculty of Education and Teacher Training \\ UIN Sunan Ampel Surabaya \\ Surabaya, Indonesia
}

\author{
Sulfiana \\ Faculty of Education and Teacher Training \\ UIN Sunan Ampel Surabaya \\ Surabaya, Indonesia
}

\begin{abstract}
The case study aims at students in the correlation between critical thinking and writing ability to analyze the students how the writing can improve the level of thinking. The main source of the data is observation in students in the third semester at English Teaching Education Department (ETED) of UINSA. This case is gotten in qualitative data by observing the class and interview with some students in the third semester in Written English (WE) class at English Teaching Education Department (ETED) of UINSA. This case study makes conclude that the results of this case are most of the students can't write with the correct grammar, not only that, but also the teachers don't understand what strategies for students.
\end{abstract}

Keywords: components, correlation research, critical thinking, writing ability

\section{INTRODUCTION}

Writing is one of the important to communication. Rodman,Formkin, and Hyams claimed that one of the important media's communication which may across space and through time is writing.In addition, in the English language, writing is one of the language skills which is important to learn by the students. Moreover, there has been one of the dominant languages used as the medium of communication in the world in terms of science and technology and in most another context of life as stated by Trask. Therefore, for students who want to develop their knowledge through English and to convey their ideas in English,it is extremely necessary. Besides that it is important for students at English Teaching Education Department of UINSA because the writing skill includes in the curriculum and the students learn it in the third semester.
In education, writing skill is an important way to communicate with someone that has lower speaking skill. Good writing skill will provide clear communication besides face-to-face or telephone communication. Besides, apart from the workplace, writing is essential in many other areas as well. Therefore, the skills of writing are essential for achieving career or business goals. However, when anyone can write everything they want, the researcher sees more and more examples of poor writing both in print and on the web. Poor writing skill will create a bad impression at first sight, and many readers will have an immediate negative reaction related to the ideas that the writers write. Regarding the students' writing ability, a problem was found that students have some difficulties in conveying their thoughts to written communication. Even though writing has been widely used as a tool for communicating ideas, but less is known about how writing can improve the level of thinking itself. It can be a lack of ideas of what to write and how to start. Being critical thinking is needed in written communication since it will provide a clear and good comprehension. In writing the right one is also not just writing but also paying attention to the content or complexity of writing.Therefore some processes and practices are very important and needed to write well. This means that not only use pens to write but also find some ideas to put on paper that are important to support the topic that researcher have been learnt.(Sugianto, 2014). According to Mattew Allen, the researcher must also combine both knowledge and information to think and practice of communicating our ideas either in written or direct, from this support to knowledge can help our thinking wider (Dalgleish et al., 2007). Additionally, there are many strategies that applied in teaching and learning processes 
include in writing. Those strategies based on the students' needs and classroom environments or the teacher's initiation. Based on Winograd and Hare, astrategy is an action that students are done to reach their goals ${ }^{1}$. Through strategy, it helps students to learn languages and achieve the learning's goal, especially in writing. Some of the strategies that often used are graphic organizer, summarizing, and critical thinking, also the others.

Relating to improving writing with the efficiency of one's academic results, critical thinkers certainly have good knowledge. Some researchers who value the use of cultural constructs claim that certain groups of learners lack critical thinking ability as displayed in their writing. They claimed that critical thinking should be learnt when they were a child. It also needs to be learnt and improved. Besides, many college faculty consider critical thinking to be one of the most important indicators of student learning quality. Ian J. Quitadamosaid, that cited from Association of American Colleges and Universities in its 2005 national report, the AACU indicated that $93 \%$ of higher education faculty perceived analytical and critical thinking to be an essential learning outcome whereas $87 \%$ of undergraduate students indicated that college experiences contributed to their ability to think analytically and creatively. This same AACU report showed that only $6 \%$ of undergraduate seniors demonstrated critical thinking proficiency based on Educational Testing Services standardized assessments from 2003 to 2004.

\section{LITERATURE REVIEW}

One of the four major of language skills is writing. Commonly,it is considered as the active of productive language skill.In this case, there is 2 researcher who claims about writing. Based on Browne, involving many skills to distinguish ideas and transfer the ideas into a piece of paper clearly and comprehensibly for the readersis complex activityof writing. In addition, Ploger said thatthe activity intended to feel of a writer about something and observe the knowledge which the result is communicated to readers writing is an/his/her audience is writing.It may be concluded that the activity that involves a series of steps to transfer thought or ideas to paper is writing. Moreover, a skill that can be developed and learned through practice which means the more often the learners practice to write, the better way will be able to write is also writing's definition.There are two researchers that claim about the writing process, from Ploeger, Ruetten and Pavlik.Ploger reveals that the writing skills covers five processes, first as planning, drafting, simmering, revising, and editing. Othe other hand, Ruettena and Pavlik stated thatin writing processthere are four stepssuch as a prewriting, drafting, revising, and editingIt means that the writing process comprises into making a preparation, planning and creating the ideas about what to writerespectively. Then, puttingthe ideas into a text, making sure whether or not the ideas are developed well,

${ }^{1}$ Hidayati.Khusnul. 2014. The Influence of Questioning Strategy on Students' Achievement in Reading. Jakarta: UIN SyarifHidayatullah Press. and rechecking the writing if there are still some errors on its such as spelling, punctuation, grammar, etc.

In writing, the researcher found, thatto do good writing, we must know about the characteristics used in writing.Hairston explainedthat in good writing,there are six characteristics;Firstly, clear (clear writing provides a clear depiction or explanation to the readers that lead them not to reread it many times to get its point or idea). Secondly, significant (writing which is considered as s significant work is if it can fulfil the readers' need. In this case, not only they can enjoy as they read it but also they can learn something from it). Thirdly, unified and well organized (A unified and well-organized writing is developed coherently; namely each sentence in a paragraph develops or support the main ideas of the paragraph and connects to sentences preceding and following it. In other words, it develops with logical sequence). Fourthly,economical (wordiness is not found in and economical writing. In this case, a writer conveys and expresses her/his ideas directly to the point). Fifthly,adequately developed (an adequately developed writing makes the readers read it easier for it is provided and supported with key points enable them to understand it well). Lastly,grammaticallyacceptable (mistakes are not found as the writing is grammatically acceptable because the standard or formal language and appropriate punctuation, as well as spelling, are applied and employed well). On the other hand, to make the good writing, it found the characteristics as asomething beneficial or knowledge is provided so that the readers will be interested in reading it, a good sequence is provided to develop the ideas of the writing are expressed clearly and directly to the point, the ideas between the sentences or paragraphs, correct grammar or usage are employed well and appropriately, andthe word choice or diction.

Critical thinking is one activity in higher education that involves many aspectsneed to consider careful. Besidesthat, critical thinking becoming one issue of interest to discuss now. Regarding this situation, some international journal and book revealed what definition of critical thinking is.Cottrell stated that critical thinking is defined as a cognitive activity associated with using the mind. Regarding to this claim, it can be considered that definition critical thinking is one of the processes which someone engages a someone's mind to find the problem.Meanwhile,critical thinking is art related art with the ability to analyze and evaluate thinking as stated by Paul and Elder (2007).It can be concluded, based on the definition andexplanations above, this is essentials that critical thinking can be considered in art or activity to think about analyze, criticize and evaluate something to raise the idea.

In this globalization era, technology is growing very rapidly and has become a major need in all walks of life. With a variety of technologies, many benefits are fulfilled by the community such as in business processes, communication and others. However, in the use of technology it also has negative effects such as the emergence of fake news in Indonesia or deception, hatred, unwanted exploitation of privacy along with the development of communication technology, especially 
young people, there will be many problems and some information where the incident allows young people to access information online and find answers to websites so easy that one does not feel the need to read a book. Phenomena like this can increase individuals becoming addicted to using the internet so that they cannot understand articles or books. This is proven, Patricia Greenfield, the renowned professor of psychology at UCLA and director of the Children's Digital Media Center, Los Angeles, stated that the ability of modern humans to think critically and analysis has declined with the advent of technology that has begun to play a greater rolewhich is in all aspects of life.A recent study conducted by MindEdge shows that many millennial generations do not have critical thinking skills. The inability to distinguish misinformation among millennial is very drastic, with $\mathbf{5 5 \%}$ of this generation relying on social media to find and read the news, while $\mathbf{5 1 \%}$ very often share content on social media, and the remaining $\mathbf{3 6 \%}$ unconsciously share information that is not accurate. As a generation of the nation, critical thinking is needed to improve the quality of individuals in analyzing and correcting all information received directly or indirectly in everyday life. By thinking critically, young people will choose accurate information and realize to eradicate the spread of something that is not true so that the country becomes more peaceful and broad-minded.

Critical thinking involves many levels of thought. In the revised Bloom Taxonomy (Krathwohl,David:2002), that is presented by involving all levels of thought where in terms of cognitive processes relating to levels or many activities. The revised divided into, first, remember(to recall or recognize knowledge which is relevant, particularly taken from long term memory. Other terms used beside remember recalland recognize). Second,understand(to consider and decide the meaning of oral or written messages received. Other variant terms of this level are interpret, exemplify, classify, summarize, infer, compare, and explain). Third, apply(to conduct something in a certain situation. Other terms used, having the same sense as apply, are executed and implement). Fourth, analyze(to divide things in an organized way and then observing the relationship between them. Other terms used other than analyze are differentiate, organize, and attribute). Fifth, evaluate (to judge something in accordance with criteria and standards. In the same sense, instead of evaluate, the terms check and critique may be used). Last,create (to produce a new original product through unifying some elements of something. Other similar terms to create are generating, plan, and produceabove presents a revised cognitive level structure Bloom's taxonomy is clearly explained, from low-level thinking level to high level thinking level).

When someone thinks critically, directly, they are able to process the mind correctly. Not only that, but also there are many benefits that can be obtained when someone is thinking critically. Cotrell argues that there are many benefits of critical thinking as follows such as work can be done carefullyand accurately, the capability to distinguish something relevant in taking notesmorespecific and accurate,ability to do problem solving and project management accurately, that can lead to feelings of confidence in the results that are successful in the complex projects and problems, and academic and work achievements can be improved better.Meanwhile, critical thinkingis possibly useful in terms of several points suchas bring the formulation of clear and accurate vital questions and problems as mentioned by Paul and Elder. Then, have the effective interpretation of information and ideas, next make conclusions and reasonable solutions that correspond to relevant criteria and standards, think inclusive or open minded, and having effective communication with others in overcoming the complex problem.

Critical thinking skills are included in high level thinking skills or Higher Order Thinking Skills (HOTS). HOTS are associated with the three upper levels of Bloom's taxonomy. Costa (1996) explained, that critical thinking particularly is defined as a thinking skill using basic thought processes to analyse arguments and give rise to insights for each meaning and interpretation, develop a pattern of cohesive and logical reasoning, understand the underlying assumption of each position, and give a presentation model that is reliable, concise and convincing. As mentioned previously, critical thinking has often been associated with learning styles. Learning styles are distinguished based on the dimensions of learning: cognitively, perceptually, and effectively, showing how to learn, understand, interact and respond to a learning environment (Hyland, 2005). In previous research on critical thinking, it has gleaned some light into various factors affecting critical thinking. One of the most identified factors is self-control that has been studied in terms of different variables, such as gender, age, grade, ethnicity, and levels of education (Bakır, 2015; Bostic, 2010; Buluş, 2011; Dunn, Rakes, \& Rakes, 2014; Fagbohungbe \& Jayeoba, 2012; Loghmani, 2010; Vierra, 2014; Wood, Saylor, \& Cohen, 2009). Another factor found to have some effect on critical thinking is learning styles (An, 2007; Roberts, 2003; Shin, Ha, \& Kim, 2005; Torres \& Cano, 1995). Some researchers have also sought to find the effects of reading and writing (Tierney, Sotter, O'Flahavan, \& Mc Ginley., 1989) and cooperative learning (Nezami, Asgari, \& Dinarvand, 2013) on critical thinking. In the same note, according to Fisher, Alec, and Scriven (1997), learning styles and metacognitive skills may have an influence on critical thinking. However, most research has not really probed into how a combination of the two factors affects critical thinking. Mostly focus on either the influence of metacognitive skills only (Gotoh, 2016; Halpern, 1998; Hanley, 1995; Paul, 1993; Pellegrino, 2007; Tishman, Jay, \& Perkins, 1992; Tsai, 2001), or on the effect of learning styles only (Andreou, Papastavrou, \& Merkouris, 2014; Wessel \& Williams, 2004; Zhang \& Lambert, 2008).

\section{METHODOLOGY}

The interview is used in the methodology to explain and answer the research question. The population of this research was the student in the third semester of English Teaching Education Department of UINSA, academic year 


\section{REFERENCES}

2018/2019. The third semester was decided as the participants of this research because ofthe consideration that they had study related writing class in written English. In addition, the third semester spread 4 class it is A, B, C, and $\mathrm{D}$ class which the researcher chose $\mathrm{B}$ class. The total participants were 30 participants, and we use quantitave to collect the data with the questionnaire as an instrument.

\section{FINDINGS AND DISCUSSION}

This case study makes conclude that the results of this case are Critical thinking is one of the writing strategies that popular among teaching and learning processes in this era even in middle age education or high level education. This strategy can help students have a sharp idea about the problem or the issues and find the solution to solve that problem then write down the idea into a written product such as story, report, essay, and free writing text. Based on Garrison (2013), critical thinking is considered as process and outcome. As the outcome, it depends on the interpretation of meaningful and understanding by an individual based on their own content specific critical ability, skills and disposition.

Moreover, the result of the students' writing is different from each other as well as their understanding ${ }^{2}$. Using critical thinking, it can help students to be more creative, innovative, and sensitive to the issues around their life; for example, students who are not really interestedin the condition of their classroom. Then, the teacher asks them to make a story to describe the classroom briefly and detail, so, it can stimulate the students to think hard and detail, what should they write in their story.Furthermore, a research study conducted by Fulan (2018) shows that critical thinking stimulates the effect of prompts on students' writing performance ${ }^{3}$.

Besides, there is another study conducted by Carter (2017) shows that to evaluate midwifery students' critical thinking in reflective writing by assessing reflective writing with the CACTIM (reflection) to develop the midwifery students' critical thinking ${ }^{4}$. Then, the study conducted by Naber (2013) that happen on nursing students shows that reflective writing can rise up the students' understanding and ability ${ }^{5}$.
[1] Ahmed, S. (2015). Rhetorical Organization of Tourism Research Article Abstracts. Procedia - Social and Behavioral Sciences (Vol. 208). Elsevier B.V. https://doi.org/10.1016/j.sbspro.2015.11.203

[2] Garrison, Randy,2013, Critical thinking, cognitive presence, and computer conferencing in distance education, London: Laurentian University.

[3] Liu, Fulan and Paul Stapleton,2018, Connecting writing assessment with critical thinking: Anexploratory study of alternative rhetorical functions and objects ofenquiry in writing prompts, Hongkong : Assessing Writing.

[4] Cartar,2017, Critical thinking evaluation in reflective writing: Development and testing ofCarter Assessment of Critical Thinking in Midwifery (Reflection),Brisbane: Griffith University. Amalia, S.,

[5] Naber, Jessica,2013, The effect of reflective writing interventions on the critical thinkingskills anddispositions of baccalaureate nursing students, United States, Elsavie
${ }^{2}$ Garrison, Randy,2013, Critical thinking, cognitive presence, and computer conferencing in distance education, London: Laurentian University.

${ }^{3}$ Liu, Fulan and Paul Stapleton,2018, Connecting writing assessment with critical thinking: An

exploratory study of alternative rhetorical functions and objects of

enquiry in writing prompts, Hongkong : Assessing Writing.

${ }^{4}$ Cartar,2017, Critical thinking evaluation in reflective writing:

Development and testing of

Carter Assessment of Critical Thinking in Midwifery

(Reflection),Brisbane: Griffith University.

${ }^{5}$ Naber, Jessica,2013, The effect of reflective writing interventions on the critical thinking

skillsanddispositions of baccalaureate nursing students, United States, Elsavier. 